\title{
Marketing Strategies in Contemporary Big Four Consulting Firms
}

\author{
MYKOLA V. MELNYK ${ }^{i}$
}

This article is about a phenomenon of Big Four companies (KPMG, Deloitte, E\&Y, PwC) who keep leading positions on the market for the last twenty years. Their way to success is a great strategy, very detailed and longstanding plan to reach new clients, reveal new products and services and employ the best students from the best universities of the world. These companies are very active in using modern and innovative solutions in their financial and marketing campaigns. Big Four stands are full of new devices, selfie-sticks and Google glasses during the Job Exhibitions, at the same time their competitors still continue to give away pens, note books and highlighters. "Innovations are in every aspect of our daily life" is a slogan of KPMG's official page dedicated to Innovations. In order to get a success and become a leader Big Four companies use diversification strategies, strategy of leadership in expenses, price differentiation strategy, specialization strategy concentrating on a niche. The descriptions and examples of all strategies mentioned above are in this article. The important place in long-term strategies with long-term perspectives take events. Professionals seminars, the publication of researches, press conferences and other PR actions, professional seminars and charity events, which have already become the integral and necessary part of marketing development tactics in consulting firms, which have resulted from globalization. High-quality services means demand higher payments, what leads to the advantage of economies of scale. PWC proved it in 2015, when they added to their portfolio business consulting. This decision created $60 \%$ of their revenue, when their standard services generated only $40 \%$. Modern ideas, fresh solutions keeping up with the times, strict following of the strategy which was created by internal specialists especially for this campaign, will to be an innovative leader, all these factors are the power of the progress. Modern world never stops. The era of new technologies is here and it changed our retrospective about the standard circle of life which is also influenced on the business as well as on the global corporations. An ability to accept global changes and to adapt to them is a talent, which guarantee success and prosperity, what is extremely important for the digital era.

Keywords: international business, E-commerce, marketing solution, business administration, marketing in economics, Scandinavian countries (Sweden, Finland, Norway).

УДК 658.8:005.21:339.13

JEL Codes: M16, M21, M31, M37, O31

The second decade of the XXI century is a complex mechanism of multinational enterprises fully-functioning and intersecting in operations with the blue chip firms on the market. The scope of strategic advices is typically seen in operations of Big Four consulting firms: referring to KPMG, Deloitte, E\&Y, PwC. Experts from these market leading companies suggest that it is necessary to create a portfolio of services, to select personnel, to develop an advertising campaign, to establish the prices, and never Vice Versa under this strategy.

Following a marketing strategy that the Big Four suggests, the following questions are to be answered: i) How do The Big Four market leaders manage to lead the entire overfilled market and

${ }^{i}$ Mykola V. Melnyk, Master 2 years Study Student of Economics Program from Vistula University in Warsaw, Poland.

(C) M. V. Melnyk, 2018.

https://doi.org/10.21272/mer.2018.82.11

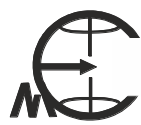

Mechanism of Economic Regulation, 2018, No 4 
М. В. Мельник. Маркетингові стратегії в сучасних консалтингових компаніях Великої Четвірки

simultaneously with the use of marketing techniques continue increasing its sales and improving performance in the long term?; ii) How to create a portfolio, what benefits and shortcomings at the universal and specialized companies and why market leaders are not changing for nearly 20 years now?. Accordingly, it is of prime importance that leading consulting firms are capable to render high-quality services demand higher payments.

The article suggests that audit and consulting firms tend to obtain on-going expenses, smaller in comparison with competitors, only due to effect of the "taking the advantage of economies of scale" related to growth of technological availability and lower cost per unit offered. Results are presented and analyzed accordingly.

Historical Aspects of Marketing Strategies. The study of mine starts from a quote of Seth Godin, who is known to be as an American author, entrepreneur. At the same time the scholar is a public speaker, known for the orientation in brand-loyalty marketing sector, leading to further studies on the basis of his experience and vision. Seth Godin is the author of several books on marketing which have high popularity worldwide. It is easy to read and perceive publications of the author. S. Godin has an extensive experience in the field of marketing as he has been in the industry over 15 intense years. Seth Godin has graduated from the university of Tafts in the direction of informatics and philosophy where he later on studied at Stanford Business School, receiving an MBA with a focus on marketing. After that, future guru of marketing was engaged in book business and has founded the Yoyodyne online company which with fast time was a part of giant Yahoo [3].

The study heavily considers strategies applicable to the market of best consulting services. Having read it, the audience will have answers to such questions as:

- How do The Big Four market leaders manage to lead the entire overfilled market and simultaneously with the use of marketing techniques continue increasing its sales and improving performance in the long term?

- How to create a portfolio, what benefits and shortcomings at the universal and specialized companies and why market leaders are not changing for nearly 20 years now?

In theory, the strategic plan of development of the company is based on the analysis of a market situation and opportunities, determines long-term tasks and prospects of development. But in practice often their heads formulate strategy of the consulting companies in classical terms: " $I$ do not want to be the black peasant, I want to lead the industry in terms of innovations!'. Heads of consulting firms, having formulated such "strategy", begin to think of those practical steps which shall help with implementation of similar transition: Whether to make the booklet on 8 pages or on 12 ? Whether to order handles with a logo for $\$ 1,24$ or to threaten directly for $\$ 1,35$ ? [8].

Nowadays, there are only four consulting and audit firms that consciously create marketing tactics and product strategies. The majority of the companies does not battle for new client, and passively relies on the existing clients, letting the market obtain oligopolistic behavior [7].

All products and services which companies create and marketing mixes which firms do for their sale shall be a consequence of strategy of the company. It is necessary to create a portfolio of services, to select personnel, to develop an advertising campaign, to establish the prices, and never Vice Versa under this strategy. At the same time, it is essentially important that, having chosen field-specific competitive strategy, managers and sales specialists exclude a losing market share. Leading to several strategies, it is inexpedient directly and it is even dangerous. Within the choice of this or that strategy specialists are including shall be defined with high degree of accuracy, than the company shall not be engaged. This choice is also important. Firms that have not chosen 
Mykola V. Melnyk. Marketing Strategies in Contemporary Big Four Consulting Firms

marketing strategy cannot be distinguished from competitors, especially in the industry of Consulting and Audit.

Never it is impossible to mix operational marketing efficiency and marketing strategy. Both of them are equally important, thus they penetrate the market in each of the potential directions (e.g. Charity Events, Exhibitions, E-Commerce, Conferences). If managers act in the same manner as other companies do, then experts from Ernst \& Young Experts claim that marketing strategies will adapt to high level of scope. However, even the best consulting organization [3] does not replace strategy without which competitors will be sooner or later ahead.

The task of implementing the strategy is a task of the top management (partners) of the company. Managers of lower level do not own complete vision and proper amount of information. For development of strategy in the company there shall be a group on development analyzing external opportunities and threats and creating the future of every business. It is vital that it is always possible to rely on subjective opinions of managers in the strategic analysis but only on the objective information which analysts are preparing internally. Additionally, all members of the big four, members of which are KPMG, Ernst \& Young, $P w C$ and Deloitte, are working in such way, where HR departments hire $20 \%$ of graduates from best rated universities in the country of operations [7].

Diversification Strategies. Every growing consulting company is faced by the choice: what types of activity to include in the list of services they are offering? The portfolio of the consulting companies comprises services with a support of holding seminars, organizing charity events, etc. Companies applying for success simultaneously monitor content of the portfolio, adding to its new, revenue-producing services and generating market profit from connections made during such events. Practically, each head of the consulting company is faced by a question whether to perform all types of consulting by own efforts or to use the technique of sub-contracting.

Eastern-European Big Four tendencies, for example, correspond to the largest western consulting companies, which tend to expand the list of services they are providing. So, Ernst \& Young and KPMG actively develop the market niche of legal services, as innovations on the market tend to conflict with countries' laws, where both firms listed above advertise their capabilities in law and audit in 2015 and 2016 inclusive. Even McKinsey, which always preferred to grow independently, has purchased the Chicago-based company Envision which is engaged in consultation in the field of branding and the technological company Informational Management in the year 2000. As ones actions are seen, the purchase itself has been immediately used as a Unique Selling Point of McKinsey.

Speaking of statistics, in $2015 P w C$ has gained only $40 \%$ of its net profit from types of activity, traditional for itself, where the other profit has been generated from consulting, rather new to PwC. In order to gain this revenue, $P w C$ had the largest expenditure on charity events in 2014 , thus attracting more connections, where it proceeded with sales of its services in 2015, when companies started planning their annual budgets (January - March) [6].

Generally, there are two streamlines for advertising diversification of services in audit and consulting. Recently-launched can either advertise developed brands, meaning invisible values of the firm (e.g. trademark) or merge or acquire informational sources (Analysis Mason, EMIS Professional).

Here is an example. Price Waterhouse Coopers has purchased firm named LVS Integrator, Deloitte has purchased JV DRT, and KPMG has purchased Kazakhstan-based firm named Bureau Zhanat. Actually, there used to be "Big Five" on the market, which changed already in 2000, 
М. В. Мельник. Маркетингові стратегії в сучасних

консалтингових компаніях Великої Четвірки

where Ernst \& Young has ended up merging with Cap Gemini, resulting in joint stock of Capgemini. This shall be interpreted as a marketing technique, since the outcome company possessed triple value (due to the rule of merger $1+1=3$ ), actively being advertised in media and operational field [2].

This strategy, according to both CEOs, is suitable for the large national audit and consulting groups which already have steady client database, indicating requests for new types of services.

Another unique feature of The Big Four is establishment of a network of partner agreements with representatives of strategic and senile industries, leading to an increase of brand loyalty and brand image. At the same time, each member of big four consulting, informs clients on updates and changes conducted, highlighting it as an improvement in their performance and level of efficiency.

Strategy of Leadership in Expenses. Considering the economic nature of consulting business, strategy of leadership in expenses and the related price leadership is unacceptable since the company incurs main costs for managing the knowledge and paying wages to employees and subcontractors. Leading consulting firms are capable to render high-quality services demand higher payments. Audit and consulting firms tend to obtain on-going expenses, smaller in comparison with competitors, only due to effect of the "taking the advantage of economies of scale" related to growth of technological availability and lower cost per unit offered.

Thus, each of the Big Four companies has the largest stands on Job Exhibitions, the most innovative presents (flash drives, virtual reality glasses, selfie-sticks etc.) all over the world, where any of the competitors is only giving away pens, magnets, block notes and highlighters. The effect does not take place because these firms is able to pay more money per unit, but instead because they are able to receive these branded products at the same price as it would cost their competitors to produce a branded pen [2].

Price Differentiation Strategy. Strategy of differentiation focuses on offering the client additional services which can be estimated as a necessary component. These benefits shall be notable and memorable. Thus, if company's services are able to be allocated from others, then firms are able to acquire the right to a price increase [1].

Example of successful strategy implementation of differentiation is the policy of the companies of "The Big Four" which have created differentiation on the basis of trusting the third parties they are hiring/sub-contracting and presenting as the best example of operational efficiency and quality-assurance in the market [4].

This group of companies has reliable protection since tried to obtain such market position for many years of work. Nowadays, the companies of "The Big Four" have no chance of competitors overcoming them, as they are spending from $11 \%$ to $16 \%$ of their net-profit on the marketing strategies and sponsorship of events worldwide. Clearly, what makes them special is the fact they are treating it as innovations, thus keeping it as a Unique Selling Point of their services, illustrating there is no conflict of interest and outstanding performance in middle and long-terms.

Specialization Strategy (Concentrating on a Niche). This strategy, according to authors, is represented in spectrum of services offered by "The Big Four" firms in 2014 and 2015 inclusive. "Innovations are in every aspect of our daily life" is a slogan of KPMG's official page dedicated to Innovations. This allows it to emphasize the importance of the effect, simultaneously offering its services to promote innovations for every client, to matter whether it is an Embassy, Ministry or a purely Private Party. 
Mykola V. Melnyk. Marketing Strategies in Contemporary Big Four Consulting Firms

Alternative option is specialization on segments of already existing markets or developing existing market niches. Establishment of the new market - labor-intensive and sometimes expensive process, but otherwise experts should compete with leaders in their markets. This is where Deloitte and $P w C$ are known from 2013 as not just tax-advisories but also exerts in strategic directions, already existing and obtaining leading market share in such industries as food production, food consumption, telecommunication and procurement, which has never been the case before 2013 [1]. How they spread and advertise the information is remaining unchanged as per year 2018:

- Each of them uses Twitter as main E-commerce tool;

- Each of them possesses mobile application with constant news and updates for individuals;

- CEOs of each of them is always conducting public-announcement, providing detailed information as per resources they are obtaining to completing projects successfully;

- Each of The Big Four firms uses SEO (tool in e-commerce) to have internet-surfing potential clients being referred to the official web-site, where the page is simplified and once analyzed with marketing experts, comes to the Minimalism style of representing the information with shortcuts to contacts and operational spectrum [5];

- Each of the firms produces and distributes weekly, monthly and quarterly reports with free distribution to strategic locations (e.g. business centers), where such updates and niches are listed and emphasized.

Generally, the company from The Big Four can choose specialization:

- on types of service (to executive coaching, preparation of annual statements);

- on the served segment (an assessment of air transport, audit of ports, matching of mechanical personnel);

- on a geographical criteria (attempt to take leadership in the local market). Such competitive line item is weak in view of the fact that consulting services can be easily rendered in any place and do not require the capital stationary equipment.

Specialization is rather difficult and courageous step as the company consciously limits to the group of clients. However in this case, every firm we are discussing, concentrates on all the marketing efforts on one segment, having narrowed at the same time all competitors involved in this segment [6].

Latest focus of the Big Four. For the analysis of opportunities of marketing development in consulting firms, it is necessary to study on-going trends that have resulted from globalization on the market. Those, specifically in the second decade of XXI century, are [1]:

- Promotion of market research and integration with the field;

- The publication of research with limited materials and free access to reports for every individual who designates to do so;

- Press conferences and other PR actions, that are always spontaneous, revolutionary and expansive, hence always generate high returns;

- Professional seminars with a monthly frequency. It is possible to hold the whole series of seminars that will also allow to compensate part of costs for research;

- The publication of research components in the mass media;

- Use of charity events to get closer to wealthy people, where the Brand itself is always printed on with large letters and logos [4].

Latest tendencies that are expected to take place in "The Big Four" 2014-2020. Advertising is still important, but marketing has much bigger value, from part today because creates area for 
М. В. Мельник. Маркетингові стратегії в сучасних консалтингових компаніях Великої Четвірки

fruitful communication between employees and clients of the company. Similar communications are capable to connect emotions of the client among which most likely there will be an increase in digital advertising in 2016 [4]. What it more important, every member-firm of the Big Four continues expanding in terms of fields they are less known in, hiring and sub-contracting experts and developing external market highlights and bursts of their new capabilities. These are presented in the following scope:

- Client-Engagement. Currently, we live in the world where pro-active consumers demand the right to vote, insist that voting rights play the leading role. It is rucial to support these ideas, specifically using elements of "control allowance" in all marketing tools: billboards, booklets, reports, official website ( $P w C 2014)$;

- Internet marketing. Internet communities, ratings and responses, interview and reviews, social networks, call centers - all of these elements provide an opportunity for training and innovating. There are more opportunities nowadays, than there used to be a decade ago, where the task of The Big Four Firms is to take an advantage of all of them, making sure they reach the highest market share or even monopolistic behavior, as in the end of the day each of them is selling services, thus Public Media, TV-Channels, Satellite TV Programs, Internet Transition, Radio and Internet Radio are experiencing second wave of demand increase, where the trend applies worldwide. During a digital era of development of the advanced devices of communications, the mobile Internet is an incentive for their growth in sales. According to the latest data, $88 \%$ of adult population globally - has mobile phone, out of which $49 \%$ are smartphones. Mobile devices became an integral part of life of most of people what marketing specialists in every of our firm, are taking an advantage. Growth of a share mobile the Internet of a traffic encourages them to reconsider location and services such as OTT, BSS and OSS [5].

- Innovative technologies that they own, tend to help them to acquire new clients. Clearly, each of the firms on the list has no restriction on place, location, segment and scope of tasks, as with the use of latest technologies and sub-contracted experts, they are serving clients on the other side of the globe, actively highlighting this capability in every of their B2B and B2C marketingrelated markets.

Thus, considering the structure of the world we are living, markets tend to be overfilled, where the market of Audit and Consulting Services possesses The Big Four market leaders for nearly 20 years now, that are growing in size and figures in black and white. Thus, each of these market leader members are actively persuading the only-four applicable to both consulting and audit marketing strategies: Diversification Strategy, Strategy Of Leadership In Expenses, Price Differentiation Strategy and Specialization Strategy (Concentration On A Niche). This focus allows them to sub-contracts specialists in various fields and then place achievements in ECommerce tools (Twitter, Mobile Apps, Online TV channel and Online Radio), develop and distribute weekly and monthly reports (KPMG Business Magazine, e-Social etc.). The upcoming years, on the other hand, are predicting concrete focus on such directions of marketing and advertising strategies/tools as Client-Engagement, Internet marketing and Innovative Technologies.

\section{References}

1. Big4.com, The 2014 Big Four Firms Performance Analysis, retrieved 02/01/2019.

2. Fetherstonhaugh, B. (2017). The 4ps Are Out, The 4es Are In. 
Mykola V. Melnyk. Marketing Strategies in Contemporary Big Four Consulting Firms

3. E\&Y, Pair digital with traditional, youth with maturity for the ultimate customer experience, official EY website, retrieved 07/01/2019.

4. Gerakosy, J., Syverson, C. (2015). Competition In The Audit Market: Policy Implications, University of Chicago Booth School of Business.

5. KPMG, EU Audit Reform, Redefining the global professional services market, 2014.

6. OECD, Competition and Regulation in Auditing and Related Professions.

7. Velte, P. \& Stiglbauer, M. Audit Market Concentration and Its Influence on Audit Quality. ISSN 19139004.

8. Statista.com, Revenue of the Big Four accounting/audit firms worldwide in 2014 (in billion U. S. dollars), retrieved 07/01/2019.

Manuscript received 8 October 2018

\author{
Маркетинговые стратегии в современных \\ консалтинговых фирмах Большой Четверки \\ НИКОЛАЙ ВАЛЕРЬЕВИЧ МЕЛЬНИК \\ *магистрант 2-го года обучения по экономике \\ Университета Вистула в Вариаве \\ ул. Стоквосы 3, Варшава, Польша, \\ тел.: +48224572 300, e-mail: melnyk.polska@gmail.com
}

Данная статья рассказывает о феномене Большой Четверки (KPMG, Deloitte, E\&Y, PwC), фирмы которой сейчас, как и 20 лет назад, занимают лидирующие позиции на рынке. Путь к успеху этим фирм - целая стратегия, пошаговый долголетний рецепт по завоеванию новых клиентов, выпуску новых продуктов услуг и прием на работу лучших студентов из списка лучших университетов всего мира. Эти компании активно применяют все инновационные подходы в своих экономических и маркетинговых стратегиях. Пока конкуренты раздают ручки с логотипами, блокноты и хайлайтерами во время дней карьеры, стенды Большой Четверки наполнены новыми инновационными устройствами, селфи-палками и очками Google. Как гласит слоган KPMG, помещенный на их официальном вебсайте: «Инновации в каждом аспекте нашей повседневной жизни». Для того, чтобы достичь поставленных задач, эти фирмы используют стратегии диверсификации, стратегию лидерства в расходах, стратегию дифференциации цен, стратегию специализации, концентрирующуюся на нише. Описания и примеры всех стратегий, упомянутых выше, находятся в этой статье. Важное место в долгосрочных стратегиях с долгосрочными перспективами занимают мероприятия. Семинары для профессионалов, публикации исследований, пресс-конференции и другие PR-акции, профессиональные семинары и благотворительные акции, которые уже стали неотъемлемой и необходимой частью тактики развития маркетинга в консалтинговых фирмах, возникшей в результате глобализации. Высококачественные услуги требуют высокой оплаты, что, в свою очередь приводит к экономическим преимуществам. Компания PWC доказала это на своем примере, когда в 2015 году добавила в свое портфолио консалтинговые услуги. Это решение составило 60 \% их прибыли, в то время как их традиционный список услуг принес $40 \%$. Новые свежие идеи, новые решения, идущие в ногу со временем, четкое следование стратегии, проработанной внутренними специалистами специально для этой компании, желание стать инновационным лидером - двигатель прогресса. Современный мир не стоит на месте. Эра новых технологий изменила наше восприятие о привычном укладе жизни, что отразилось на бизнесе, в том числе, и на мировых корпорациях. Способность принимать перемены и адаптироваться - это талант, который гарантирует успех и процветание, что особенно важно в эре цифровых технологий. 
М. В. Мельник. Маркетингові стратегії в сучасних

консалтингових компаніях Великої Четвірки

Ключевые слова: международный бизнес, электронная коммерция, маркетинговое решение, бизнес-администрирование, маркетинг в экономике, страны Скандинавии (Швеция, Финляндия, Норвегия).

\author{
Mechanism of Economic Regulation, 2018, No 4, 119-126 \\ ISSN 1726-8699 (print) \\ Маркетингові стратегії в сучасних
консалтингових компаніях Великої Четвірки \\ МИКОЛА ВАЛЕРІйОВИч МЕЛЬНИК* \\ *магістрант 2-го року з економіки \\ Університету Вістула у Варшаві \\ вул. Стоквоси 3, Варшава, Польща, \\ тел.: +48224572 300, e-mail: melnyk.polska@gmail.com
}

Дана стаття описує феномен Великої Четвірки (KPMG, Deloitte, E\&Y, PwC), яка, як 20 років тому, так і зараз займає лідируючі позиції на ринку. Їхні шляхи до успіху - ціла стратегія, спланована крок за кроком і націлена на пошук нових клієнтів, випуск нових продуктів та наймають на роботу найкращих студентів зі списку найкращих університетів усього світу. Ці компанії активно застосовують усі доступні інноваційні підходи в своїх економічних і маркетингових стратегіях. У той момент, як під час Днів Праці конкуренти нажаль роздають ручки, блокноти та маркери з логотипами своїх компаній, стенди Великої Четвірки приковують увагу новими інноваційними пристроями, селфіпалками та окулярами Google. Як проголошує слоган KPMG, розміщений на їх офіційній вебсторінці: «Інновації у кожному аспекті нашого повсякденного життя». Для того, щоб досягти поставленої мети, ці фірми використовують стратегії диверсифікації, лідерства, спеціалізації з концентрацією на своїй ніші. Детальний опис і приклад до кожної вищезгаданої стратегії є у статті. Важливе місце у довготермінових стратегіях $з$ довготерміновими перспективами займають заходи, організовані для професіоналів, різноманітні семінари, публікації досліджень, прес-конференції та інші PR-акції і благодійні акції. Всі вони вже стали невід‘ємною i необхідною частиною тактики розвитку маркетингу у консалтингових фірмах і повстали внаслідок глобалізації. Високоякісні послуги вимагають високої оплати, що в свою чергу призводить до економічних переваг. Компанія РWC довела це на своєму прикладі, коли в 2015 році додала до свого портфоліо консалтингові послуги. Це рішення склало $60 \%$ прибутку, в той час як традиційний список послуг приніс усього $40 \%$. Нові свіжі ідеї та рішення, що йдуть в ногу з часом, чітке дотримання стратегії, опрацьованої внутрішніми фахівцями спеціально для компанії, та бажання бути інноваційним лідером - двигун прогресу. Сучасний світ не стоїть на місці. Ера нових технологій змінила наше сприйняття про основу щоденного укладу життя, що не могло не відбитися на бізнесі, в тому числі, і на світових корпораціях. Здатність приймати зміни і адаптуватися - це талант, який гарантує успіх і процвітання, що особливо важливо в еру розвитку цифрових технологій.

Ключові слова: міжнародний бізнес, електронна комерція, маркетингове рішення, бізнесадміністрування, маркетинг в економіці, країни Скандинавії (Швеція, Фінляндія, Норвегія).

JEL Codes: M16, M21, M31, M37, O31

References: 8

Language of the article: English 